\title{
D-DIMER AS A POTENTIAL PREDICTOR OF THROMBOEMBOLIC AND CARDIOVASCULAR COMPLICATIONS IN PATIENTS WITH CHRONIC KIDNEY DISEASE
}

\author{
I. S. MYKHALOIKO ${ }^{1 \bowtie}$, I. O. DUDAR ${ }^{2}$, I. Ja. MYKHALOIKO ${ }^{1}$, O. Ja. MYKHALOIKO \\ ${ }^{1}$ SHEE “Ivano-Frankivsk National Medical University”, Ivano-Frankivsk, Ukraine; \\ ${ }^{2} S I$ "Institute of Nephrology AMS of Ukraine", Kiev, Ukraine; \\ 凶e-mail: iralisn@gmail.com
}

Received: 13 February 2020; Accepted: 30 June 2020

\begin{abstract}
The aim of the study was to evaluate the relationship between D-dimer levels and different biomarkers of renal diseases to identify the relationship between hypercoagulation and chronic kidney disease (CKD). To achieve this aim, we conducted a one-step prospective observational study involving 140 patients with CKD who were hospitalized in Ivano-Frankivsk Regional Clinical Hospital in Ukraine during 2018-2019. Of these patients, 100 patients (71.4\%; 95\% CI 53.4-76.7) had glomerulonephritis (GN) and 40 patients (28,6\%; 95\% CI 21.3-36.8) had diabetic nephropathy (DN). All patients underwent standard examination, which included general clinical, biochemical and instrumental research methods. D-dimer was quantitatively determined in blood serum by enzyme-linked immunosorbent assay (ELISA). The 140 patients were divided into two groups according to the level of D-dimers: normal level $(<0.5 \mathrm{mg} / \mathrm{l})$ and elevated level $(\geq 0.5 \mathrm{mg} / \mathrm{l})$. Elevated $D$-dimer levels were associated with an increased age of patients, decreased glomerular filtration rate, decreased blood albumin level, increased daily protein excretion and a tendency to develop thromboembolic complications during 1 year of monitoring. D-dimer is a biological marker that can detect hypercoagulation at an early preclinical stage in patients with CKD and identify patients with an increased cardiovascular risk, thereby promoting the earliest use of antiplatelet agents and anticoagulants and, consequently, it can reduce mortality.
\end{abstract}

Ke y w o rd s: chronic kidney disease, glomerulonephritis, diabetic nephropathy, hypercoagulation, D-dimer.

\section{Introduction}

Chronic kidney disease (CKD) is a global health care problem. Existing CKD significantly increases the risk of death, especially because of cardiovascular complications [1].

Patients with kidney diseases are prone to both thrombosis and bleeding. The prothrombotic state in CKD, especially in glomerular diseases, is associated with: vascular endothelial damage, increase in certain coagulation factors and antifibrinolytic factors, decrease in anticoagulant proteins, dyslipidemia, nephrotic syndrome and hypoalbuminemia, and changes in thrombocyte membranes. The risk of thromboembolic complications increases 2,5-fold in CKD stages II-III, and 5,5-fold in CKD stages III-IV [2].
However, in the same patients the risk of bleeding significantly increases due to platelet dysfunction, impaired platelet interaction with blood vessels, taking certain medicines (antiplatelet agents, anticoagulants), vascular wall disorders, comorbidities and coexisting conditions (anemia, myeloma, amyloidosis with kidney lesions) and dialysis treatment [3].

Understanding the nature and severity of changes in the indicators of the hemostasis system in patients with CKD will allow timely application of therapy with antiplatelet agents and anticoagulants [4].

D-dimer is a specific product of decay (degradation) of fibrin fibers under the action of plasmin and some non-specific fibrinolytics. The concentra-

(C) 2020 Mykhaloiko I. S. et al. This is an open-access article distributed under the terms of the Creative Commons Attribution License, which permits unrestricted use, distribution, and reproduction in any medium, provided the original author and source are credited. 
tion of D-dimer in blood serum is proportional to the activity of fibrinolysis and the amount of lysed fibrin [5]. The level of D-dimer indicates the intensity of the fibrin clots' formation and destruction processes. The elimination half-time of D-dimer is about 8 hours, with clearance carried out through the kidneys and reticuloendothelial system [6].

$\mathrm{D}$-dimer is considered to be a marker of hypercoagulation and endogenous fibrinolysis. It is a sensitive marker for the diagnosis of disseminated intravascular coagulation (DIC) syndrome and for monitoring the dynamics of initiated therapy [7]. D-dimer is an independent risk factor for cardiovascular death and coronary heart disease, and its utility as a marker in subclinical thrombophilia has been shown [8]. A normal level of D-dimer excludes the presence of thrombosis and DIC-syndrome in patients with a probability of $85-90 \%$, its elevated levels indicate hypercoagulation and require further studies to visualize thrombi [6].

The objective of our study was to evaluate the relationship between D-dimer levels and different biomarkers of renal diseases to identify the relationship between hypercoagulation and CKD.

\section{Materials and Methods}

We conducted a one-step prospective observational study involving 140 patients with CKD who were hospitalized at the Ivano-Frankivsk Regional Clinical Hospital (Ukraine) during 2018-2019. Of these patients, 100 patients (71.4\%; 95\% CI 53.476.7) had glomerulonephritis (GN) and 40 patients (28.6\%; 95\% CI 21.3-36.8) had diabetic nephropathy (DN). Among the patients, there were more men ( $n=92$, 65.7\%; 95\% CI 57.2-73.5) than women ( $n=48,34.3 \%$; 95\% CI 26.5-42.8). The average age of the patients was 46 years $(41 ; 49)$.

The clinical diagnosis was determined based on standard methods of examination of patients according to the classification of kidney diseases and protocols of management of patients with CKD. All studies were performed in compliance with the provisions of the Council of Europe Convention on Human Rights and Biomedicine and the recommendations of the Bioethics Committee of the Presidium of the National Academy of Medical Sciences of Ukraine (Kyiv 2014, 2016).

During the study, a standard examination was performed on all patients, which included general clinical, biochemical and instrumental research methods. Biochemical tests and enzyme-linked im- munosorbent assays (ELISAs) were performed in the laboratory of Ivano-Frankivsk Regional Clinical Hospital. The research was performed in accordance with international standards for the coordinated participation of respondents, the ethical component of research and biomaterial collection. All patients signed a written informed consent to participate in the study.

The glomerular filtration rate (GFR) was determined using a CKD-EPI calculator (https://nephrology.kiev.ua/eGFR/gfr.htm). Daily protein excretion (DPE) is a marker for assessment of the functional status of the kidneys, and was determined by colorimetric method (Dialab, Wiener Neudorf, Austria) in urine collected within 24 hours. Urine should be stored at a temperature of $2-25^{\circ} \mathrm{C}$. DPE reference value: $<300 \mathrm{mg} /$ day. The urinary albumin/creatinine ratio (ACR) was determined using the method of turbidimetry from urine specimens collected in the morning. ACR reference value: $<30 \mathrm{mg} / \mathrm{g}$.

Blood obtained from the patient's ulnar vein (on an empty stomach) was used to study D-dimer. Blood serum was separated from erythrocytes by centrifugation (3000 rpm) for $10 \mathrm{~min}$. Serum was stored at a temperature of $2-6^{\circ} \mathrm{C}$. The analysis was performed up to $12 \mathrm{~h}$ from the time of blood collection.

D-dimer was determined in blood serum quantitatively by ELISA using a set of reagents (Getein Biotech, Nanjing, China). The test uses D-dimer monoclonal antibodies conjugated to colloidal gold applied in the test area. After application of the test sample of blood serum on the pad of the test strip, D-dimer monoclonal antibodies interact with the D-dimer in the sample and form an antigen-antibody complex. After that, the test cassette was inserted into the ELISA FIA8000 (Getein Biotech, Nanjing, China) to quantify the level of D-dimer.

Reference value for D-dimer levels: the concentration of D-dimers in blood serum of healthy people with no thrombotic risk was $<0.5 \mathrm{mg} / \mathrm{l}$. The 140 patients were divided into two groups based on D-dimer levels: normal level $(<0.5 \mathrm{mg} / \mathrm{l})$ and elevated level $(\geq 0.5 \mathrm{mg} / \mathrm{l})$.

STATISTICA 10 software (StatSoft, USA) was used for statistical analysis. The frequency of qualitative indicators was presented in absolute $(n)$ and relative (\%) frequencies with the indication of the $95 \%$ confidence interval (CI) in the form of " $n$ (\%; $95 \% \mathrm{CI})$ ". When analyzing quantitative data, it was necessary to determine the nature of the distribu- 
tion of indicator values using Shpiro-Wilk's test. For quantitative data with a normal distribution, the results were represented as "M $(\sigma)$," where M is the mean value and $\sigma$ is the standard deviation. For quantitative data with an abnormal distribution, "Me $\left(\mathrm{q}_{1} ; \mathrm{q}_{2}\right)$ " was used, where Me is the median and $\mathrm{q}_{1} ; \mathrm{q}_{2}$ are quartiles. Quantitative indicators with normal distribution of values in 2 independent groups were compared using the Student's criterion. Quantitative parameters with abnormal distribution in 2 independent groups were compared using the MannWhitney method. Comparison of 2 independent groups for the qualitative indicator was carried out according to the exact Fisher criterion.

Correlation of normal distributions was assessed by determining the Pearson correlation coefficient, and in the abnormal distribution by the Spearman's rank correlation coefficient. A $P$-value of $<0.05$ was considered to be statistically significant.

\section{Results and Discussion}

CKD stage I was diagnosed in 36 patients (25.7\%; 95\% CI 18.7-33.8), CKD stage II - in 21 patients (15.0\%; 95\% CI 9.5-22.0), CKD stage IIIa - in 24 patients (17.1\%; 95\% CI 11,3-24,4), CKD stage IIIb - in 31 patients (22.1\%; 95\% CI 15.6-29.9) and
CKD stage IV - in 28 patients (20.0\%; 95\% CI 13.727.6).

In 86 patients (61.4\%; 95\% CI 52.8-69.5) with GN and DN urinary syndrome was present, and in 54 patients (38.6\%; 95\% CI 30.5-47.2) nephrotic syndrome occurred.

In 25 patients (17.9\%; 95\% CI 11.9-25.2) the diagnosis of GN was confirmed morphologically, as follows: in 11 patients (44.0\%; 95\% CI 24.4-65.1) mesangioproliferative GN was confirmed, and 5 patients (20.0\%; 95\% CI 6.8-40.7) had membranous nephropathy, 4 patients (16.0\%; 95\% CI 4.5-36.1) had focal-segmental glomerulosclerosis, 3 patients (12.0\%; 95\% CI 2.5-31.2) had nephropathy with minimal changes, and 2 patients (8.0\%; 95\% CI 1.0-26.0) had membrane proliferative (mesangiocapillary) GN.

D-dimer levels $(<0.5 \mathrm{mg} / \mathrm{l})$ were normal in 56 patients (40.0\%; 95\% CI 31.8-48.6), but were elevated $(\geq 0.5 \mathrm{mg} / \mathrm{l})$ in 84 patients $(60.0 \%, 95 \% \mathrm{CI}$ 51.4-68.2). Based on the D-dimer levels, patients were divided into 2 groups (Table).

As can be seen in the Table, elevated levels of D-dimers were associated with an increased age of patients, decreased GFR, decreased blood albumin, increased DPE and a tendency to develop thromboembolic complications during 1 year of monitoring.

Characteristics of patients with diabetic nephropathy (DN) and glomerulonephritis (GN) according to the levels of D-dimer

\begin{tabular}{|c|c|c|c|}
\hline Characteristics of patients & $\begin{array}{l}\text { Patients with normal } \\
\text { D-dimer levels } \\
(<0.5 \mathrm{mg} / \mathrm{l}), n=56\end{array}$ & $\begin{array}{c}\text { Patients with elevated } \\
\text { D-dimer levels } \\
(\geq 0.5 \mathrm{mg} / \mathrm{l}), n=84\end{array}$ & $P$ value \\
\hline Sex, male (\%; 95\% CI) & $62.5(48.5-75.1)$ & $67.9(56.8-77.6)$ & $P=0.586$ \\
\hline Sex, female (\%; 95\% CI) & $37.5(24.9-51.5)$ & $32,1(22.4-43.2)$ & $P=0.586$ \\
\hline Age, years Me $\left(\mathrm{q}_{1} ; \mathrm{q}_{2}\right)$ & 37 (34; 42) & $48(44 ; 51)$ & $P<0.001$ \\
\hline Disease duration, years, $\mathrm{Me}\left(\mathrm{q}_{1} ; \mathrm{q}_{2}\right)$ & $10(7 ; 14)$ & $12(8 ; 16)$ & $P>0.05$ \\
\hline Creatinine, mmol/l, Me $\left(\mathrm{q}_{1} ; \mathrm{q}_{2}\right)$ & 122.5 (91.4; 143.3) & 178.2 (135.2; 243.8) & $P<0.05$ \\
\hline Urea, mg/dl, Me $\left(q_{1} ; q_{2}\right)$ & $9.4(7.8 ; 11,3)$ & $16.8(12.5 ; 18.3)$ & $P<0.05$ \\
\hline GFR, ml/min/1.73 m3, Me $\left(\mathrm{q}_{1} ; \mathrm{q}_{2}\right)$ & $92(81 ; 113)$ & $66(43 ; 84)$ & $P<0.05$ \\
\hline Albumin levels, g/l, Me $\left(\mathrm{q}_{1} ; \mathrm{q}_{2}\right)$ & $32.4(28.3 ; 34.7)$ & $25.4(22.1 ; 27.4)$ & $P<0.05$ \\
\hline DPE, mg/day, Me $\left(\mathrm{q}_{1} ; \mathrm{q}_{2}\right)$ & 1232 (923; 1545) & 3242 (1987; 4324) & $P<0.05$ \\
\hline ACR, mg/g Me (q1; $\left.q_{2}\right)$ & $98(51 ; 189)$ & $378(256 ; 578)$ & $P<0.001$ \\
\hline D-dimer, mg/l, Me $\left(\mathrm{q}_{1} ; \mathrm{q}_{2}\right)$ & $0.35(0.26 ; 0.44)$ & $1.53(1.12 ; 2.15)$ & $P<0.001$ \\
\hline $\begin{array}{l}\text { Thrombotic complications, } \\
\text { (\%; 95\% CI) }\end{array}$ & $0(0.0-6.4)$ & $6.0(2.0-13.3)$ & $P=0.157$ \\
\hline
\end{tabular}

ACR - albumin/creatinine ratio, CI - confidence interval, DPE - daily protein excretion, GFR - glomerular filtration rate; $\mathrm{Me}\left(\mathrm{q}_{1} ; \mathrm{q}_{2}\right)$ - median and quartiles 
While there were more men than women in both groups, the difference was not statistically significant $(P=0.586)$.

Thromboembolic complications occurred in 5 of 84 patients (6.0\%; 95\% CI 2.0-13.3) with elevated levels of D-dimers. There were deep vein thromboses of the lower extremities in 4 patients $(4.8 \%$; $95 \%$ CI 1.3-11.7) and renal vein thrombosis in 1 patient (1.2\%; 95\% CI 0.0-6.5).

After performing correlation analysis, we found a direct weak correlation between the age of patients and the $\mathrm{D}$-dimer level $(r=0.235, P<0.05)$, an inverse average correlation between the GFR and the D-dimer level ( $r=-0.614, P<0.05$, Fig. 1$)$, an inverse average correlation between the blood albumin level and the D-dimer level $(r=-0.467, P<0.05)$, and a direct medium-strength correlation between DPE and the D-dimer level $(r=0.367, P<0.05)$ (Fig. 2).

Some studies have found an association between increased D-dimer levels and elevated DPE levels and decreased GFR in patients with diabetes mellitus [9, 10]. It was postulated that the association between decreased GFR and elevated D-dimer levels in patients with diabetes mellitus was due to the increased formation of D-dimers rather than decreased urinary excretion of this marker, as it was shown that patients with DN had higher levels of D-dimers in their urine than healthy people [11]. It was also determined that important natural anticoagulant proteins (such as antithrombin, protein C, protein S) are lost in the urine during high proteinuria, which enhances

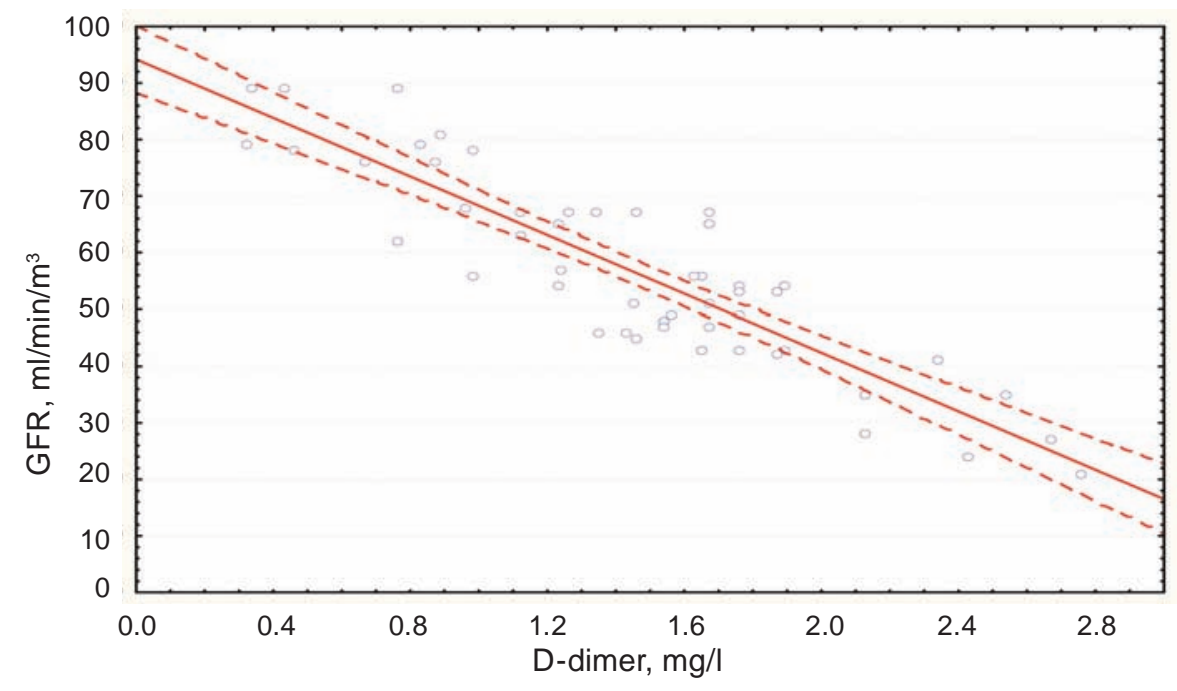

Fig.1. The correlation between the glomerular filtration rate (GFR) and D-dimer levels

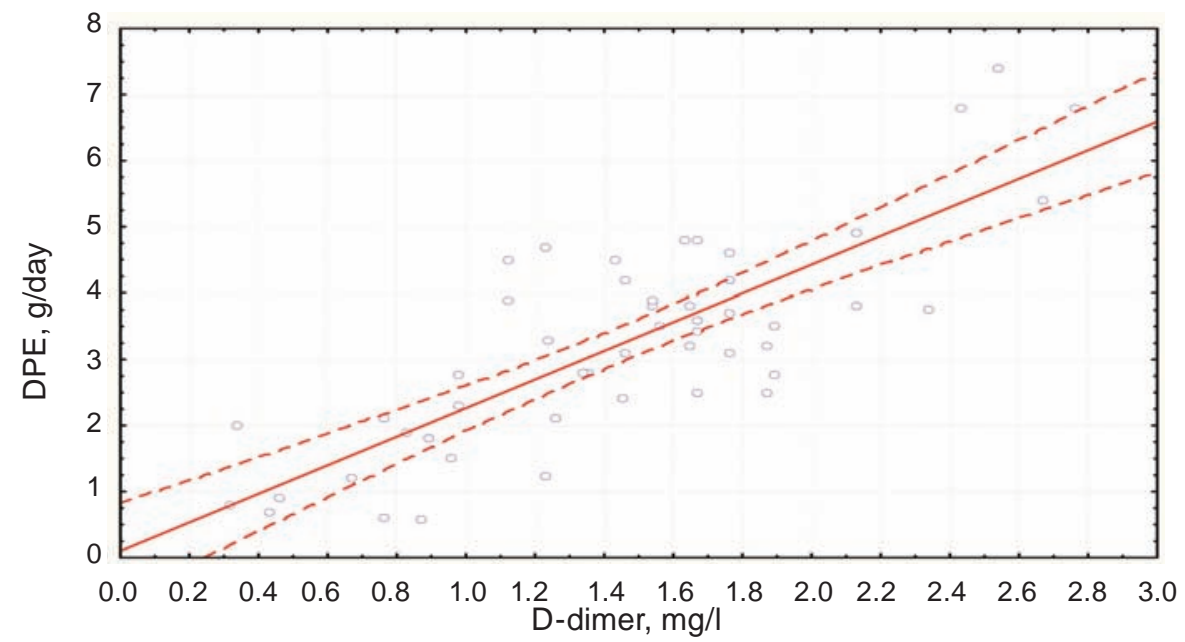

Fig.2. The correlation between daily protein excretion (DPE) and D-dimer levels 
the state of hypercoagulation and the formation of D-dimers [12]. Furthermore, it was hypothesized that the decreased GFR also leads to endothelial dysfunction and the release of Von Willebrand factor, which promotes platelet adhesion and aggregation and the formation of microthrombi, and thus an increase in D-dimer levels [13].

Haase et al. (2013) and others demonstrated that D-dimer levels increase with age, which was also found in our study. These results can be explained by the development of age-related changes in microcirculation and blood clotting, which contribute to the creation of hypercoagulation status and a gradual increase in D-dimer levels with aging [14].

\section{Conclusions}

Elevated levels of D-dimers are associated with an increased age of patients, decreased GFR, decreased blood albumin level, increased DPE and a tendency to develop thromboembolic complications during 1 year of monitoring.

D-dimer is a biological marker that can detect hypercoagulation at an early preclinical stage in patients with CKD and identify patients with an increased cardiovascular risk, thereby promoting the earliest use of antiplatelet agents and anticoagulants and, consequently, it can reduce mortality.

Prospects for further research. In our opinion, it would be interesting to study the levels of D-dimers depending on the type of treatment received (cytostatics, hormones, anticoagulants, antiplatelet agents), as well as depending on the morphological variant of GN. Also, certainly, longer monitoring of patients is required to better describe the thromboembolic and cardiovascular complications in patients with CKD.

Conflict of interest. Authors have completed the Unified Conflicts of Interest form at http://ukrbiochemjournal.org/wp-content/uploads/2018/12/coi_ disclosure.pdf and declare no conflict of interest.

\section{D-ДИМЕР ЯК ПОТЕНЦІЙНИЙ \\ ПРЕДИКТОР РОЗВИТКУ \\ ТРОМБОЕМБОЛІЧНИХ ТА \\ КАРДІОВАСКУЛЯРНИХ \\ УСКЛАДНЕНЬ У ХВОРИХ НА \\ ХРОНІЧНУ ХВОРОБУ НИРОК}

I. С. Михалойко ${ }^{1 凶}$, I. О. Дудар²,

I. Я. Михалойко, О. Я. Михалойко

${ }^{1}$ ДВНЗ «Івано-Франківський національний медичний університет», Україна;

${ }^{2} Д У$ «Інститут нефрології НАМН України», Київ;

凶e-mail: iralisn@gmail.com

Метою дослідження було оцінити зв'язок між рівнями D-димерів та різними біомаркерами ниркових захворювань для виявлення взаємозв'язку між гіперкоагуляцією та хронічною хворобою нирок (XXН). Для вирішення поставленої мети нами було проведено одномоментне проспективне обсерваційне дослідження із залученням 140 пацієнтів i3 XXН, які перебували на стаціонарному лікуванні в Івано-Франківській обласній клінічній лікарні протягом 2018-2019 років, 3 них $100(71,4 \%)$ хворих на гломерулонефрит i $40(28,6 \%)$ на діабетичну нефропатію. Під час дослідження проведено стандартне обстеження хворих загальноклінічними, біохімічними та інструментальними методами. D-димер визначали кількісно за допомогою імуноензимного аналізу з використанням набору реагентів Getein Biotech (Китай). Bcix пацієнтів було поділено на дві групи за рівнем D-димерів: нормальний рівень D-димерів $(<0,5$ мг/л) і високий рівень $\mathrm{D}$-димерів $(\geq 0,5$ мг/л). Підвищений рівень D-димерів асоціюється 3 підвищеним віком хворих, зниженням швидкості клубочкової фільтрації, зниженим рівнем альбуміну крові, підвищеною добовою екскрецією протеїну та тенденцією до розвитку тромбоемболічних ускладнень, які виникли у хворих протягом 
року спостереження. Зроблено висновок, що $\mathrm{D}$-димер є біологічним маркером, який здатен виявляти гіперкоагуляцію на ранній доклінічній стадії у хворих на ХXН, визначити пацієнтів iз підвищеним ризиком кардіоваскулярних i тромбоемболічних подій, сприяти якнайшвидшому застосуванню в них антиагрегантної i антикоагулянтної терапії i, як наслідок, зменшувати смертність.

К л ю ч о в і с ло в а: хронічна хвороба нирок, гломерулонефрит, діабетична нефропатія, гіперкоагуляція, D-димер.

\section{References}

1. Kolesnyk M. Innovative directions of CKD prevention and treatment. Ukr J Nephr Dial. 2019; 1(61): 3-12.

2. Christiansen CF, Schmidt M, Lamberg AL, Horváth-Puhó E, Baron JA, B Jespersen B, Sørensen HT. Kidney disease and risk of venous thromboembolism: a nationwide populationbased case-control study. J Thromb Haemost. 2014; 12(9): 1449-1454.

3. Pavord S, Myers B. Bleeding and thrombotic complications of kidney disease. Blood Rev. 2011; 25(6): 271-278.

4. Folsom AR, Lutsey PL, Astor BC, Wattanakit K, Heckbert SR, Cushman M, Atherosclerosis Risk in Communities Study. Chronic kidney disease and venous thromboembolism: a prospective study. Nephrol Dial Transplant. 2010; 25(10): 3296-3301.

5. Tan X, Chen G, Liu Y, Zhou L, He L, Liu D, Liu Ye, Zhang F, Li H, Liu H. Serum D-dimer is a potential predictor for thromboembolism complications in patients with renal biopsy. Sci Rep. 2017; 7(1): 4836.

6. Pulivarthi S, Gurram MK. Effectiveness of d-dimer as a screening test for venous thromboembolism: an update. $N$ Am J Med Sci. 2014; 6(10): 491-499.
7. Sextona DJ, Clarksona MR, Mazura MJ, Planta WD, Eustacea JA. Serum D-dimer concentrations in nephrotic syndrome track with albuminuria, not estimated glomerular filtration rate. Am J Nephrol. 2012; 36(6): 554-560.

8. Mohammed NMS, Khalil HBE. D-dimer levels in patients presenting chronic kidney disease in Sudan. Am J Med Med Sci. 2016; 6(3): 120-122.

9. Wakabayashi I, Masuda H. Association of D-dimer with microalbuminuria in patients with type 2 diabetes mellitus. J Thromb Thrombolysis. 2009; 27(1): 29-35.

10. Domingueti CP, Fóscolo RB, Dusse LMS, Reis JS, das Graças Carvalho M, Gomes KB, Fernandes AP. Association of different biomarkers of renal function with D-dimer levels in patients with type 1 diabetes mellitus (renal biomarkers and D-dimer in diabetes. Arch Endocrinol Metab. 2018; 62(1): 27-33.

11. Shibata T, Magari Y, Mizunaga S, Okabe E, Sumie A, Ishii T, Tomo T, Yasumori R, Nasu M. Significance of urinary fibrin/fibrinogen degradation product (FDP) D-dimer measured by highly sensitive ELISA method with a new monoclonal antibody (D-D E72) in various renal diseases. Nihon Jinzo Gakkai Shi. 1994; 36(7): 805-812. (In Japanese).

12. Kato S, Chernyavsky S, Tokita JE, Shimada YJ, Homel P, Rosen H, Winchester J. Relationship between proteinuria and venous thromboembolism. J Thromb Thrombolysis. 2010; 30(3): 281-285.

13. Jenkins PV, O'Donnell JS. ABO blood group determines plasma von Willebrand factor levels: a biologic function after all? Transfusion. 2006; 46(10): 1836-1844.

14. Haase C, Joergensen M, Ellervik C, Joergensen MK, Bathum L. Age- and sexdependent reference intervals for D-dimer: evidence for a marked increase by age. Thromb Res. 2013; 132(6): 676-680. 